\title{
Геннадій Кривчик
}

Дніпровський начіональний університет залізничного транспорту імені академіка В. Лазаряна

\section{Децентралізація влади в Україні на тлі пандемії COVID-19}

Децентралізація і коронавірус - ось два слова, які останнім часом найбільш часто вживаються в інформаційному просторі України. Тож актуальність теми даної статті $є$ подвійною, адже вона випливає з двох актуальних соціальних і політичних проблем, що розглядаються у статті, - проблеми організації боротьби з падемією COVID-19 i доленосної для України реформи децентралізації влади.

Метою статті є об’єктивний аналіз процесу децентралізації влади в умовах серйозного виклику, що повстав перед українською державою через пандемію коронавірусу. Для цього застосована методологія історичної науки. Дослідження базується на принципах історизму, об’єктивності, конкретності, системності; при написанні статті використані діалектичний, аналітичний, описовий методи.

Розглянуто події завершального етапу реформи децентралізації влади (2020р.), коли роз'язувалися завдання укрупнення районів, формування нового адміністративно-теритріального устрою країни, проведення виборів до нових районних рад і громад. При цьому все це здійснювалося в умовах економічної кризи, пандемії COVID-19, зниження життєвого рівня більшості людей, падіння довіри до усіх гілок влади. Важливою проблемою децентралізації влади стало дотримання балансу державних і регіональних інтересів, налагодження 3 цією метою взаємодії між центральною владою і місцевими елітами, мерами великих міст, роль яких підвищилася у зв’язку 3 антивірусними заходами. Показником цього став успішний виступ на місцевих виборах регіональних партій i особисто чинних мерів.

Наукова новизна статті полягає в тому, що в ній уперше розглянуто проведення реформи децентралізації державного управління в умовах небаченої раніше пандемії, яка поставила під загрозу виживання великих мас людей, економіку, суспільний устрій України. Як і в більшості країн світу.

Ключові слова: реформа, місиеве самоврядування, демократія, об'єднані територіальні громади (ОТГ), пандемія, коронавірус, карантин

\section{Hennadiy Kryvchyk}

Dnipro National University of Raiway Transport Named after Acadmician V. Lazaryan

\section{Decentralization of power in Ukraine in the conditions of the COVID-19}

Decentralization and coronavirus - these are the two words that have recently been most often used in the information space of Ukraine. Therefore, the relevance of the topic of this article is twofold, as it stems from two current social and political issues addressed in the article - the fight against coronavirus and the fateful reform of decentralization of power for Ukraine.

The purpose of the article is an objective analysis of the process of decentralization of power in the face of a serious challenge facing the Ukrainian state due to the coronavirus pandemic. The methodology of historical science is used for this purpose. The study is based on the principles of historicism, objectivity, specificity, systematics; analytical, descriptive methods were used in writing the article.

The events of the final stage of the decentralization reform phase (2020) are considered, when the tasks of consolidation of districts, formation of a new administrative-territorial structure of the country, holding elections to new district councils and communities were solved. At the same time, all this was carried out in the context of the economic crisis, the coronavirus pandemic, the decline in the living standards of most people, and the decline in confidence in all branches of government. An important problem of decentralization of power has been the balance of state and regional interests, the establishment of interaction between the central government and local elites, mayors of large cities, whose role has increased due to anti-virus measures. An indicator of this was the successful performance in the local elections of regional parties and personally acting mayors.

The novelty of the article is that it first considers the reform of decentralization of public administration in an unprecedented pandemic, which threatened the survival of large masses of people, the economy, the social order of Ukraine. Like most countries in the world.

Keywords: reform, local self-government, democracy, united territorial communities (UTG), pandemic, coronavirus, quarantine 


\section{Постановка проблеми}

Пецентралізація влади та зміцнення місцевого самоврядування $є$ одним iз найбільш актуальних завдань, що необх дно розв'язати в процесі розбудови Української держави. Метою реформи децентралізації, яка була задекларована Урядом i розпочалася в 2014 р., є формування ефективного самоврядування та територіальної організації влади для створення i підтримки повноцінного життєвого середовища для громадян, надання високоякісних та доступних публічних послуг, становлення інститутів прямого народовладдя, узгоджених інтересів держави та територіальних громад. Реформа передбачає відповідальність органів місцевого самоврядування перед жителями за ефективність своєї роботи, а перед державою - за її законність (Реформа децентралізації, 2020)

Дана стаття $\epsilon$ продовженням публікацій автора,щоприсвяченіпередумовамтапершому етапу децентралізації в Україні (Євсеєва, \& Кривчик, 2019), Кривчик, 2019), (Кривчик, 2020). Однак з часу публікації указаних статей завершився вже другий етап реформи, за результатами якого відбулися значні зміни, які призвели реформу децентралізації до логічного кінця. Час підвести підсумки. Можна побачити плюси і мінуси реформи, уточнити iii ефективність. Особливість реформування на цьому етапі полягає в тому, що воно здійснювалося в умовах дуже серйозного виклику, яким стала пандемія COVID -19.

Природно, що вказані сучасні процеси знайшли відображення в чисельних публікаціях, насамперед у публіцистиці, яка зі зрозумілих причин більш оперативно, ніж наука, реагує на поточні події в країні. Публікації публіцистичного характеру можна поділити на дві групи. Перша - це апологетика реформи - статті, що написані здебільшого урядовцями. До цієї групи, зокрема, можна віднести пропагандистські виступи Міністра розвитку громад i територій В. Негоди (2020) та народного депутата, лідера партії «Нам тут жити» I. Полихаєва, який переконаний, що децентрализация не просто метод вирішення актуальних проблем, а й едине правильна можливість розвитку країни на сучасному етапі (Полыхаев, 2020).
Приклад іншого, критичного підходу низка публікацій науковців і журналістів. Зокрема, статті екс-глави Рахункової палати України, д. е. н. В. Симоненка (Симоненко, 2020), головного наукового співробітника Інституту економіки i прогнозування НАН України О. Попової (Попова, 2020), а також редактора відділу політики тижневика «Дзеркало тижня» I. Ведернікової (Ведернікова, 2020) та директора Центру суспільно-політичного моніторингу «Вектор» М. Філонова - автора низки статей у «Українській правді» (Філонов, 2019а), (Філонов, 2019b), (Філонов, 2019c,) (Філонов, 2020). Перша група публікацій характеризується інформаційною насиченістю, але ій, як правило, бракує критичного погляду на політику децентралізації; другу характеризує аналітичність, хоча подеколи, на наш погляд, цьому дещо заважає надмірна емоційність суджень авторів.

Мета даної статті - зробити об' єктивний аналіз процесу децентралізації влади в Україні в умовах серйозного виклику, що повстав у 2020 р. перед країною через пандемію коронавірусу. Для цього використана методологія історичної науки 3 iii принципами історизму, конкретності, системності та методами дослідження діалектичним, аналітичним, описовим тощо.

\section{Виклад основного матеріалу}

Процес децентралізації влади розпочався в 2014 р. 3 прийняття концепції реформи місцевого самоврядування та територіальної організації влади в Україні (1.04.2014), законів України «Про співробітництво територіальних громад (17.06.2014), «Про добровільне об'єднання територіальних громад (05.02.2015) та змін до бюджетного i Податкового кодексів щодо фінансової децентралізації. Головна ідея децентралізації - максимальне делегування повноважень на місця.

На першому етапі реформи децентралізації влади (2014-2018 рр.) вирішуваллися задачі повсюдного створення об'єднаних територіальних громад (ОТГ) i наданням їм певної господарської та фінансової самостійності. А щоб було за що ці повноваження виконувати, Уряд у 2014 р. провів фінансову децентралізацію, віддавши ОТГ частину загальних державних 
видатків та перевів їх на прямі відносини 3 державним бюджетом. За 5 років децентралізації об'єдналися чи приєдналися до вже створених ОТГ 4572 громади. Це майже 42 \% від усіх територіальних грромад (Прокопчук, 2019). Окремі сильні громади завдяки цьому досягли чималих успіхів у вдосконаленні соціальнокультурної інфраструктури своїх населених пунктів. Однак у 2019 р. процес утворення ОТГ дещо уповільнився через політичні події, що пов'язані 3 президентськими й парламентськими виборами, а потім - 3 формуванням нової управлінської команди на чолі 3 Президентом В. Зеленським. На початок 2020 р. в Україні нараховувалося понад 1400 ОТГ, у яких об'єдналося 4800 громад, 44\% от загального числа територіальних громад (Децентрализацию нельзя отменить или остановить, 2020). Решта населених пунктів (56\%) потребувала об'єднання.

Попри декларовану добровільність створеняя ОТГ, місцеві державні адміністрації - як попередні, так і нові нерідко застосовували для прискорення вказаного процесу прямі й приховані примусові методи. За підрахунками В. Симоненка, на добровільних засадах у ОТГ об'єдналося тільки $33 \%$ територіальних громад, інші - адміністративними методами. Крім того, по суті, критерій створення ОТГ був один - кількість населення (Симоненко, 2020). Не були враховані соціальноекономічні, культурні особливості, наявність місцевих регіональних традицій тощо.

Поза сумнівом, деякі позитивні зрушення від децентралізації відчули на собі міські громади, які отримали певну самоійність i більші фінансові можливості для благустрою міст. Щодо сільських громад, то тут не все так просто. До деяких об'єднаних громад увійшло по 30-40 селищ і сіл, що ускладнило надання адміністративних послуг селянам. Крім того, значна частина сільських громад увійшла в ОТГ, центрами яких стали міста обласного значення, через що у сільського населення зменшилися можливості впливати на вирішення справ на своїх територіях. Сільські громади в перспективі також можуть втратити частину своєї землі. Тож, на думку О. Попової, примусова децентралізація - це позбавлення сіл і селян як земель, так і суб’єктності (Попова, 2020). Тим не менш у лютому 2020 р. Д. Шмигаль (тоді ще віце-прем'єр-міністр-міністр розвитку громад i територій України) заявив, що адміністративно-територіальна реформа одна 3 найбільш успішних і одна 3 найбільш зрозумілих для українців.

Він також додав, що другий етап реформи децентралізації має розпочатися 3 адміністративно-територіальної реформи i завершитися місцевими виборами цієї осені. За словами Д. Шмигаля, ще один крок - внесення змін до Основного Закону - Конституції, щоб привести в порядок той адміністративно-територіальний устрій, який ми отримали після виборів у сформовані місцеві громади, відповідно до перспективних планів (Дискуссия о децентрализации, 2020).

На цьому етапі також необхідно було: сформувати перспективні плани, які мають стати основою для створення спроможних громад 3 оптимальними мережами публічних послуг; переформатувати місцеві адміністрації в органи префектурного типу; прийняти статути територіальних громад місцевими радами; провести місцеві вибори на новій територіальній основі: Автономна республіка Крим, 24 області, місто Київ, 100 районів (округів), 1400 громад (Децентралізація. Урядовий портал, 2020).

Продовженням політики створення об’єднаних територіальних громад стало укрупнення районів. У травні 2020 р. Мінекономрозвитку, звітувавши про завершення першого етапу реформи, повідомило, що в період наступного етапу замість 490 наявних районів мають бути сформовані 118 укрупнених районів. Представники місцевих влад закликали Раду не поспішати з реорганізацією районів. Більше ніж 200 представників місцевих влад зверталися із закликом до Верховної Ради не голосувати за будь-які закони і постанови про реорганізацію районів і не оголошувати вибори до райрад, поки не завершаться консультації відносно кінцевого бачення децентралізації. Під зверненням підписалися голови громадських організацій, експерти, депутати місцевих рад, голови ОТГ, мери міст. У зверненні наполягалося на тому, щоб спочатку був внесений на розгляд Ради проект змін до Конституції щодо 
децентралізації, з тексту якого має випливати кінцеве бачення того, яку роль влада відводить субрегіональному рівню, а вже потім щоб вносилися інші законопроекти, які будуть «приводити законодавство в гармонію 3 новим конституційним устроєм» (Рада уменьшила количество районов, 2020).

Незважаючи на звернення представників органів місцевого самоврядування, Уряд вирішив провести укрупнення районів, пояснюючи це тим, що наявний адміністративно-територіальний устрій виник ще в радянські часи й він не відповідає «сучасним стандартам». Райони було запропоновано перекроїти так, щоб вони включали мінімум 150 тис. населення. Райцентрами визначено населені пункти 3 населенням не менше, ніж 50 тис. населення. При цьому найбільш віддалені села мають знаходитися на відстані не більше, ніж 60 км від райцентру. Невдовзі Кабмін вирішив, що більш оптимальне число районів - 129, однак остаточну кількість районів визначила Верховна Рада України. Відповідно до Постанови ВРУ від 17 липня 2020 р. «Про утворення та ліквідацію районів» адміністративно-територіальний устрій України включив 136 районів (Про утворення та ліквідацію районів, 2020).

Однак у зазначеній постанові містився лише перелік районів, які створювалися за принципом укрупнення. Визначення ïx функцій, статусу, прав i обов'язків районних рад у документі було відсутнє. Сказано були тільки, що вибори районних рад у ліквідованих районах не проводяться. Залишалися неопрацьованими система i порядок передачі власності ліквідованих районів новоствореним, що на місцях породжувало, за словами В. Симоненка, відчуття хаосу в системі місцевого самоврядування (Симоненко, В., 2020).

Владі також закидали, що створення нового районного поділу відбулося не за законом України, а постановою Верховної Ради, тобто здійснено в антиконституційний спосіб; що новий районний поділ суперечить раніше декларованим владою цілям реформи децентралізації; що він ускладнить життя багатьох людей, особливо в сільській місцевості, адже зі зменшенням числа районів, обов'язково зменшиться в сільській місцевості кількість поліклінік, лікарень, освітніх установ, різноманітних установ соціального обслуговування i послуг, які в обов'язковому порядку закріплюються за кожною районною структурою. Так і сталося. Наприклад, у Житомирській області створили 4 райони: Коростенський, Новоград-Волинський, Житомирський, Бердичевський. При цьому деякі села були відрізані від райцентрів на великі відстані. Наприклад, селище Любар, яке було центром Любарського району з населенням у 27 тис. людей, стало належати до Житомиру, до якого 82 км (а не 60 , як закладалося у первісному проекті). Половина цього шляху - по поганій дорозі до Чуднова, і тільки звідси траса стає кращою. Це означає, що добиратися до райцентру жителі Любара будуть близько 2-х годин. У Донецькій області створили величезний Краматорський район, який об'єднав майже всю північ регіону і до якого увійшла вся північнодонецька агломерація, що включла Слов'янськ, Краматорськ, Дружківку, Костянтинівку. Новий крій може призвести до маси незручностей на місцях. Багатьом жителям районів для отримання соціальних і адміністративних послуг доведеться тепер їздити за тридев'ять земель. Самі послуги стануть менш доступними географічно. Реформа особливо сильно вдарила по пенсіонерах, літніх людях. Наприклад, на Житомирщині створили Житомирський район. Відстань від села Пиріжки до центру району - 150 км (Студенникова, 2020). До того ж утворення нових районів не зажди відповідало раціональним критеріям. Так, у Чекаській області кілька сіл лівобережної частини Канівського району передали не до сусідньої Золотоноші, а до дальніх правобережних Черкас. Така ж історія у багатьох регіонах країни. Народний депутат IV-VIII скликань, лідер партії «Наша країна» М. Томенко вбачає, що при утворенні як об'єднаних громад, так і укрупнених районів не обійшлося без задоволення комерційних інтресів місцевих землевласників та політичних інтересів чиновників (Томенко, 2021).

Становище ускладнювалося тим, що завершення реформи децентралізації відбувався в дуже складних умовах пов'язаних між собою економічною кризою, погіршенням життєвого рівня великої 
кількості людей і пандемією коронавірусу. Ще в грудні 2019 р. в китайському місті Ухань відбувся спалах невідомого раніше штаму коронавірусу - «2019-nCoV». Лише за місяць (станом на 30 січня) у Китаї померло від нього понад 170 осіб, ще близько 8 тис. захворіли. Дуже швидко вірус поширився й у інших країнах: Південній Кореї, Італії, Іспанії, Японії, США, невдовзі практично по всьму світові. У грудні 2020 р. у світі діагностували 75 млн хворих, близько 1,7 млн 3 них померли (По скорости распространения covid-19, 2020). У зв'язку початком пандемії Всесвітня організація охорони здоров'я оголосила надзвичайний стан міжнародного рівня.

В Україні коронавірус уперше був діагностований 3 березня 2020 p. у Чернівцях. 13 березня був зафіксования перший летальний випадок. Менше ніж за рік, 23 грудня 2020 р., кількість українців, що заразилися на коронавірус, перевалила за 1 мільйон (Кількість українців, 2020).

Дуже важкими виявилися наслідки коронавірусу для економіки України. Замість очікуваного зростання ВВП країни на 4,5 \% 2020 -й рік приніс падіння на $6 \%$. Різниця між прогнозованим і реальним показником понад $8 \%$. У грошовому еквіваленті втрати від коронакризи за рік для реального сектору економіки оцінюваються більше ніж у 10 млрд доларів (Дранник, 2020).

Як тільки Всесвітня організація охорони здоров'я повідомила про початок пандемії 11 березня), Кабінет Міністрів України прийняв рішення запровадити в країні трьохтижневий карантин. На цей період було призупинено навчання у дошкільних закладах, школах, закладах вищої освіти, закриті місйця масового скупчення людей (торговельні центри, кінотеатри), заборонені масові заходи чисельністю понад 200 людей. 14 березня Президент В. Зеленський увів у дію постанову РНБО про протидію коронавірусу, яким передбачалося закриття пунктів пропуску на кордоні та тимчасова заборна в 'їзду іноземців в Україну. 16 березня Кабмін за ініціативою Президента посилив карантинні заходи, зокрема заборонив роботу метро, міжміські перевезення та масові заходи за участю понад 10 осіб, заборонив людям гуляти в парках i скверах. Для громадського транспорту був встановлений ліміт у 10 пасажирів. Одночасно, йдучи назустріч бізнесу, Уряд прийняв рішення про звільнення підприємців на час карантинув від податків на землю й нерухомість.

В організації боротьби 3 пандемією, центральна влада воліла спертися на президентську вертикаль влади, насамперед на призначених губернаторів. Також зробила спробу залучити до справи олігархів, закріпивши за ними цілі регіони. Натомість, по суті, відлучили від боротьби з пандемією, як і загалом від реальної політики, органи місцевого самоврядування. Нібито через те, що ті були сформовані за часів попереднього режиму. 3 цього приводу 21 березня 2020 р. кілька мерів на ток-шоу С. Шустера заявили, що не мають ані найменшої комунікації 3 президентською вертикаллю влади, i це не сприяє консолідації всіх зусиль у подоланні епідемії та успішному проведенні децентралізації.

Між тим ситуація з пандемією вимагала від Уряду саме посилення комунікації 3 місцевими радами мерами i місцевими громадами, де краще, ніж у Києві, знали ситуацію в регіонах. Через небажання дослухатися до думки очільників міст центральна влада в період карантину зробила низку помилок, які мусила потім виправляти, втрачаючи свій авторитет. Адже, як радив класик політтехнології Н. Маккіавеллі: «Рішення государя щодо приватних справ підданих повинні бути безповоротними i думка повинна бути такою, щоб нікому не могло прийти в голову, що можна обдурити або перехитрити государя» (Маккиавелли, 2019, с. 86).

Серйозну репутаційну втрату понесла влада від заборони відвідувати у період карантину парки й сквери. Ще більшою помилкою, за загальною думкою, стало звільнення піприємців від податків на землю і нерухомість на час карантину. Причому всіх підприємців. Незалежно від того чи вони працюють, чи мусили припинити роботу. У результаті місцеві бюджети тільки в березні сукупно втратили $13 \%$ дохідної частини (Ведернікова, 2020).

Однак при цьму саме органи місцевого самоврядування виносили на собі основний тягар організації боротьби 3 пандемією. Щодо олігархів, на допомогу яких розраховував президент, то вони дали в 
травні 375 млн грн на ліквідацію ковіду. Відтак органи місцевого самоврядування, за словами києвського градоначальника В. Кличка, залишилися у боротьбі з пандемією можна сказати сам-на-сам і уже місяць усі міста від маленьких до великих шукають маски, засоби захисту для лікарів, гроші, спонсорів (Ведернікова, 2020).

До того ж влада компроментувала себе подвійними стандартами. Так, у зв'язку 3 карантинними обмеженнями була заборонена робота дрібних підприємств торгівлі i побутового обслуговування населення. Але водночас чомусь було дозволено працювати великим торговельним центрам (таким як «Епіцентри»), які за відсутності конкуренції отримали змогу збільшувати свої прибутки. Широкого суспільного розголосу набув також «велюровий скандал», що розгорівся в квітні 2020 р. Тоді журналісти Bihus info з'ясували, що попри карантинні заборони працює елітний ресторан «Велюр», що належить депутату від «Слуги народу» М. Тищенку, його відвідують провладні політики. Такі подвійні стандарти обурювали людей. Не випадково у ці дні ЗМІ неодноразово цитували Дж. Оруелла: «Всі тварини рівні, але деякі тварини більш рівні ніж інші» (Оруелл, 2009).

Малі підприємства несли вличезні збитки, деякі мусили призупинити свою роботу або банкрутіли. Тільки в квітні 2020 р. припинили діяльність 13,3 тис. дрібних підпрємств - ФОПів (ФОП - фізична особапідприємець) (В апреле закрылись, 2020). Згідно 3 даними соціологічного опитування дослідницької компанії «Градус», у травні 2020 р. $15 \%$ українців опинилися на грані виживання через карантин, 21 \% відчували сильні матеріальні труднощі, а ще 38 \% відчували сильні фінансові проблеми (Ищенко, Тимофеев, 2020).

Настрої людей дуже швидко відчули мери міст. Адже вони були ближче, ніж центральна влада, до людей. Деякі 3 них відкрито виступили проти надмірних, наїхню думку, карантинних обмежень. Очевидно, не останню роль відіграло й їхнє бажання отримати додаткові електоральні симпатії напередодні місцевих виборів. Прикметним став гострий конфлікт між президентом В.ЗеленськимімеромЧеркасА.Бондаренком, коли останній під час карантину у зв'язку
3 пандемією COVID-19 навесні 2020 р., пафосно кинув виклик центральній владі. Він заявив, що місто в односторонньому порядку відмовляється від карантинних обмежень і не збирається виконувати вказівки з Києва, а на погрозу завести на нього кримінальну справу додав, що ні президент, ні міністр внутрішніх справ не можуть наказувати чи погрожувати йому. Всупереч забороні в Черкасах було дозволено працювати магазинам 3 продажу непродовольчих товарів, будівельних матеріалів, сантехніки, канцелярських товарів, меблів тощо, відкриті майстерні надання різних побутових послуг, перукарн, відкриті ярмарки 3 продажу сільськогосподарської продукції. На мера Черкас завели кримінальну справу (мер побачив у цьому політичні репресіi), а Президент В. Зеленський назвав його «бандитом, 3 яким не сяде за один стіл» (Бондаренко, 2020). У результаті А. Бондаренко отримав додатковий піар, який допоміг переобратися міським головою.

Прагнучи дистанціюватися від центральної влади і загальноукраїнсьих партій, рейтинг яких похитнувся, мери великих міст вирішили навесні 2020 р. створити власні політичні проекти. Думки про те, що на наступних місцевих виборах успіх будуть мати регіональні партії, висувалися в ЗМІ ще в минулому році. Нехитре гасло «Голосуйте за своїх!», як стверджувалося, може стати ефективним в умовах розчарування більшості громадян діяльністю загальнонаціональних партій, які не воліють задовольняти потреб жителів міст і сіл країни (Філонов, 2019а). Ця ідея набула актуальнсті у зв'язку з наближенням дати місцевих виборів.

У квітні 2020 р. на політичному полі України утворюється партія «Пропозиція», засновниками якої були міські голови: Дніпра - Б. Філатов, Миколаєва - О. Сенкевич, Чернівців - О. Каспрук, Житомира С. Сухомлин, Кропивницького А. Райкович, Каховки - А. Дяченко. За словами Б. Філатова, «партія мерів» існуватиме поза ідеологією, але навряд чи цю заяву можна вважати щирою - 3 перших днів ця партія задекларувала мету посилення ролі регіонів у вирішенні загальнодержавних справ. Одночасно в Запоріжжі була утворена партія мера В. Буряка «Сднання», а мер 
Києва В. Кличко знову очолив свою партію «Удар».

На місцевих виборах восени 2020 р. регіональні партї провели чимало своїх представників до місцевих рад та на посади міських голів. Щоправда, за результатами виборів до обласних рад і міста Києва представники загальноукраїнських партій посіли провідні місця: «Слуга народу» отримала $17,3 \%$ місць, «Європейська солідарність» - $15,9 \%$, «Опозиційна платформа - За життя!» - 12,92 \%. Натомість локальні партії набрали від $0,28 \%$ - «Блок Володимира Сальдо» до $2,52 \%$ - «Блок Кернеса - успішний Харків». Однак в окремо взятих округах саме вони стали переможцями та призерами виборів, відтиснувши «Слугу народу» та інші старі партії. Ще більше своїх кандидатів провели локальні партії до районних і міських рад (Місцеві вибори, 2020). Крім того, пропрезидентська партія «Слуга народу» не спромоглася привести свого представника на посаду міського голови у жодному великому місті, обласному центрі. I навіть на «малій батьківщині» Президента - у Кривому Розі переміг не представник «Слуги народу», якого підтримував особисто В. Зеленський, а К. Павлов - представник «Опозиційної платформи - За житя», який дуже різко критикував центральну владу (Манчук, 2020).

Завершення другого

етапу децентралізації відбувалося в умовах другої хвилі пандемії корнавірусу, через що Уряд України продовжив карантинні обмеження, a згодом прийняв рішення запровадити протягом 11-30 листопада «карантин вихідного дня», за якого припинялася у вихідні дні робота непродуктових магазинів, ресторанів, кінотеатрів, театрів, торгівельно-розважальних комплексів тощо. Однак мали рацію деякі епідеміологи, бізнесмени, журналісти, народні депутати, які попереджали, що цей карантин є поганою ідеєю, адже люди, які планували зробити необхідні покупки в суботу чи в неділю, усе одно зроблять їх у будні дні, тільки це буде вже зроблено в умовах більшої скупченості покупців на одному квадратному метрі, а підприємці, які зачинили свої магазини на вихідні дні, втратять більше половини своїх прибутків. Люди жартували: вирогідно,
COVID-19 особливо небезпечний у вихідні дні, а в будні він тимчасово відпочиває (Костин, 2020). Однак Уряд знов не почув людей, не відреагував на акцію протесту підприємців, так званих ФОПів (ФОП - фізична особа-підприємець), які напередодні прийняття рішення про запроваждження «карантину вихідного дня» прийшли під стіни будинку будинку Кабміну i розпочали акцію «SaveФОП». Рішення було все одно прийнято - й сталося так, як i попереджали підприємці. Магазини, підприємства громадського харчування й побутового обслуговування зазнали великих збитків, деякі припинили свою роботу, що, однак, аніскільки не змешило кількості захворювань.

Складна економічна та епідеміологічна ситуація в країні та не дуже втішні результати, що показала на місцевих виборах правляча партія «Слуга народу», не завадили центральній владі здійснити новий крок щодо завершення реформи децентралізації. 17 листопада Верховна Рада України прийняла Закон «Про внесення змін до деяких законів України щодо врегулювааня окремих питань організації та діяльності органів місцевого самоврядування i районних державних адміністрацій», згідно 3 яким дана можливість новообраним органам місцевого громад і районів. Закон регулює питання правонаступництва комунального i державного майна, бюджетних ресурсів, прав та зобов'язань, а також дав змогу створити державні адміністрації (Про внесення змін до деяких законів України щодо врегулювааня окремих питань організації та діяльності органів місцевого самоврядування i районних державних адміністрацій, 2020). Прийнятий закон запропонував нові правові механізми для повноцінної роботи місцевого самоврядування. Так, новий закон регулює питання правонаступництва комунального i державного майна, бюджетних ресурсів, прав і обов'язків. Також закон дозволив створювати районні державні адміністрації у зв'язку зі змінами в адміністративнотериторіальному устрої країни. Він відрегулював питання про повноваження i правонаступництво органів місцевого самоврядування, унормував питання призначення виборів старост у затверджених територіальних громадах. 
На виконання зазначеного Закону Кабінет Міністрів України прийняв постанову, якою затвердив заходи щодо утворення та реорганізації районних державних адміністрацій, а також правонаступництва щодо майна, прав та обов'язків районних державних адміністрацій, що припиняються (Про затвердження Порядку здійснення заходів, 2020). Уряд прийняв також низку розпоряджень, за якими реорганізував та утворив 119 районних державних адміністрацій, зробив подання кандидатур на посади голів РДА та призначення їх Президентом України. Був сформований новий склад РДА, які мають забезпечити взаємодію 3 новообраними районними радами та спільно вирішувати нагальні завдання.

Прикметно, що в зазначених документах йшлося про взаємдію органів центральної влади, президентської вертикалі влади 3 органами місцевого самоврядування й не згадувалося про ідею перетворення державних адміністрації в «органи префектурного типу», що мали керувати місцевим самоврядуваням та могли їх розпустити.

У грудні 2020 р. відновила роботу Рада регіонального розвитку, що свідчило про те, що нова влада врешті-решт усвідомила необхідність налагодити взаємозв'язки 3 місцевими громадами. Не можна не погодитися зі знаним політологом В. Фесенком, який написав на одному 3 інтернет-порталів, що це абсолютно правильне рішення, особливо в умовах децентралізації та після місцевих виборів: «Слід вибудовувати конструктивний діалог 3 місцевими елітами, тим більше перед спільними викликами (Фесенко, 2020).

Очевидно, що негативні для центральної влади результати виборів допомогли їй розпочати більш раціонально вибудувати свої відносини з місцевим самоврядуванням. Щодо органів місцевого самоврядування й місцевих еліт, які значною мірою впливають на політику громад, то вони теж почали усвідомлювати, що конфронтація з центром ні до чого хорошого не принесе ані державі, ані самим регіонам і місцевим громадам. Принаймні, після своєї перемоги на виборах міській голова А. Бондаренко знайшов сили, щоб вибачитися перед Президентом: «Ми мусимо забути про протистояння між мером i Президентом. На сьогоднішній день я, як міський голова, хотів би в першу чергу вибачитися перед Президентом за те, що я, в принципі, не себе відстоював, а мешканців міста» (Мэр Черкасс извинился перед Зеленскими, 2020).

\section{Висновки}

Вирішення завдань подолання економічної кризи, що була посилена пандемією коронавірусу, черговий раз засвідчило необхідність встановлення балансу загальнодержавних і регіональних інтересів, взаємодії центральних органів влади, президенської вертикалі 3 органами місцевого самоврядування. Органи місцевого самоврядування, які утворюються населенням певної адміністративно-територіальної одиниці, мусять виконувати свої зобов'язання перед виборцями, тобто дбати про розвиток своїх територій чи населених пунктів, відстоювати й захищати їх жителів - своїх виборців. Розвиток кожного міста, кожної території - це розвиток всієї країни. Благополуччя i добробут кожної людини - це благополуччя й процвітання держави. Органи місцевого самоврядування покликані враховувати загальнодержавні інтереси у прийнятті своїх рішень i діях. Вони мусять виступати у ролі посередників між державою і громадами, роз'яснювати й реалізовувати політику держави. У разі необхідності відстоювати саме загальнодержавні інтереси, не допускати виникнення місцевого егоїзму й сепаратизму.

Завдання акумулювати центральної енергію

влади суспільства, консолідуватидіяльністьусіхйогоскладових, пом'ятаючи, що всі регіони різні, їх неможна стригти під один гребенець. Як писав Антуан де Сент-Екзюпері: «Зібрати в єдине ціле означає зв'язати міцно-міцно все розмаїття, всі особливості, а не нищити їх заради бесплодного порядку (Сент-Екзюпери, 2007, c. 153). 3 іншого боку, реалізація інтересів окремої громади не повинна завдавати шкоди загальнодержавним інтересам.

Попри твердження деяких чиновників про завершення реформи децентралізації, попереду постають нові завдання в напрямку поглиблення реформи, наповнення іiі 
демократичним змістом. На часі внесення обіцяних змін до Конституції України та прийняття таких законодавчих актів, які чітко регламентують повноваження й фінансові ресурси, що мусять залишатися на місцях.

\section{БІБЛІОГРАФІЧНІ ПОСИЛАННЯ}

Анатолий Бондаренко: Что известно о мэре Черкасс, его политическое прошлое и любимый Mercedes. 2020. URL: vybory.24tv.ua/ru/anatolij_bondarenko_biografija kto_jeto_bondarenko_chto isvestno_n1337398.

В апреле закрылись более 13 тыс ФЛП. Зеркало недели. 2020,18 мая. URL: zn.ua/ECONOMIC̄S/v-aprele-zakrylisbolee-13-tysyach-flp354614_html

Ведернікова I. Без точки опори. Але в одному човні. 2020. URL: zn.ua/internal/bez-tochki-opori-ale-v-odnomuchovni-34353 .html.

Децентралізація. Урядовий портал. 2020. URL: decentralization.gov.ua/news/11909.

«Децентрализацию нельзя отменить или остановить»- В'ясчеслав Негода. Зеркало недели. 2020, 17 марта. URL: zn.ua/UKRAINE/my-esche-ne-pereshli-ekvator-ekspert-o-prodvizhenii-reformy-decentralizacii-348226_html.

Дискуссия о децентрализации в областях продолжится на протяжении двух недель. Интерфакс Украина. 29.02.20. URL: interfax.com.ua/news/political/644060.html.

Дранник А. Привет, карантин! События недели. 2020, 15 дек.

Євсеєва Г.П. , Кривчик Г. Г. Формування системи місцевого управління в Україні. Державне управління та місиеве самоврядування: зб.наук. пр. Дніпро: ДРІДУ НАДУ. 2019. Вип. 1(40). С. $13-20$.

Игорь Полыхаев: Децентрализация - единственно правильная возможность развития Украины. 2020. URL: 112.ua/politika/igor-kolyhaev-decentralizaciya--edinstvenno-pravilnaya-vozmozhnost-razvitiya-ukrainy-537//2.html.

Ищенко Ф., Тимофеев И. Страна на карантине: сколько украинцев оказалось на грани выживания. Сегодня. 2020, 26 мая.

Кількість українців, що заразилися на COVID, перевалило за 1 мільйон. 2020. URL:pravda.com.ua/ news/2020/12/24/727804.

Костин И. Ковид выходного дня. 2000 (еженедельник). 2020, №40. 20-26 нояб. URL: 2000.ua/v-nomere/forum/ plus/kovid-vyhodnogo-dna.htm.

Кривчик Г. Г. Впровадження і результати першого етапу децентралізації української влади (2014 - 2019 рр.). Правові аспекти публічного управління: теорія і практика: матеріали XI наук.-практ.конф.12 груд.2019 р., м. Дніпро: ДРІДУ НАДУ, 2019. С. 18-21.

Кривчик Г.Г. Децентралізація української влади: концепція, впровадження, результати ії першого етапу (20142018 рр.). Universum Historiae et Archeologiae. 2019. Т. 2, Вип. 2. С. 95 - 106.

Маккиавелли Н. Государь. О военном искусстве / пер. с итал. Москва : Изд-во АСТ, 2019. 392 с. html.

МанчукА.Кривойрог:какЗеленскийпроигралнасвоемполе.2020.URL:ukraina.ru/opinion/20201208/1029887567.

Місцеві вибори в Україні. 2020. URL: uk.wikepedia.org/wiki/Miсцеві_вибори_в_Україні_2020.

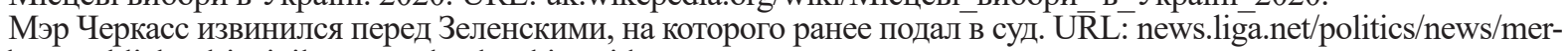
cherkass-publichnol-izvinilsya-pered-zelenskim-video.

Негода В. Децентралізацію не можна скасувати або зупинити. 2020. URL: zn.ua/UKRAINE/mu-esche-neperechli-ekvator-ekspert-o-prodvzhenii-reformy-decentralizacii-348226/html.

Оруэлл, Дж. Скотный двор. Глава Х. Москва : ACT, 2009. URL: loveread. ec/view_global.php?id=19865.

По скорости распространения covid-19 Украина уступает только четырем странам Европы. Украинская правда. 2020. URL: pravda.com.ua/rus/news/2020/12/197277511/.

Прокопчук Ф. Децентралізація на фініші: чи завершать реформу за 9 місяців? 2019. URL: hromadske.ua/posts/ decentralizaciya-na-finishi-chi-zavershat-reformu-za-9-misyaciv.

Про внесення змін до деяких законів України щодо врегулювааня окремих питань організації та діяльності органів місцевого самоврядування і районних державних адміністрацій : Закон України від 17.11.2020 p. №1009-ІХ. URL: zakon.rada.gov.ua/laws/show/1009-IX\#Text.

Про затвердження Порядку здійснення заходів щодо утворення та реорганізації районних державних адміністрацій, а також правонаступництва щодо майна, прав та обов'язків районних державних адміністрацій, що припиняютьсяя : Постанова Кабінету Міністрів України від 16 грудня 2020 p. №1321. URL: www.kmu.gov.ua/npas/ pro-zatverdzhennya-poryadku-zdijsntnnya-zahodiv-shodo-rajonih-derzhavnih-administracij-1321-161.

Рада уменьшила количество районов в Украине: 136 вместо 490. Украинская правда. 2020, 17 лип. URL: pravda. com.ua/rus/news/2020/07/07/7259715/.

Реформа децентралізації. Урядовий портал. 2020. URL: www.knu.gov.ua/ diyalnist/reformi/efectivne-(2020) vryaduvannya/reforma-dectntralizaciyi.

Сент-Екзюпери, А. де. Цитадель / сб., пер.с фр. Москва : АСТ ХРАНИТЕЛЬ, 2020. 368 с.

Симоненко В. Тупик судьбоносной реформы. Вечерняя Одесса. 2020, 20 окт.

Студенникова Г. Уволить бюджетников, внести хаос перед выборами.Зачем Рада вчетверо уменьшила количество районов. 2020. URL: strana.ua/news/279322-novaja-karta-rajonov-ukrainy-zachem-ukrupnili-rajthentry.html.

Попова О. Адміністративний форсаж. Чим загрожує прискорення реформи самоврядування. 2020. URL: zn.ua/economics of regions/administrativnyy forsazh-chem-ugrozhaet

Томенко М. $\overline{(20 \overline{2} 1)}$ Децентрализация по схемам правнуков Кагановича. 2021. URL: obozrevatel.com/person/ nikolaj-tomenko.htm. 
Фесенко В. (2020). То, что считают изобретением Зеленского, работало и при Кучме, и при Януковиче

// strana.ua/opinions/305503-to-chto-schtajut-izobreteniem-zelenskogo-rabotalo-i-prikuchme-i-pri-janukoviche.htul. Філонов М. Партії регіонів. Українська правда. 2019, 18 груд. URL: pravda.com.ua/columns/2019/12/18/.

Філонов М. Наступна зупинка -місцеві вибори. Украӥнська правда. 2019, 1 серп. URL: pravda.com.ua/ columns/2019/08/1/7222512/.

Філонов М. Політичний джекпот «43 мільйони». Яка доля чекає на переможця і країну? Украӥнська правда. 2019, 7 лист. URL: pravda.com.ua/columns/2019/07/11.

Філонов М. «Слуга народу» і реформи. Вибори програли, децентралізацію зупинили. Украӥнська правда. 2020, 27 лист. URL: pravda.com.ua/columns/2020/11/27/.

\section{REFERENCES}

Anatoly Bondarenko: What is known about the mayor of Cherkassy, his political past and his beloved Mercedes. (2020). Retrieved from vybory.24tv.ua/ru/anatolij_bondarenko_biografija_kto_jeto_bondarenko_ chto_isvestno_n1337398 [in Russian].

About the consolidated procedure for the establishment of visits to the establishment and reorganization of regional state administrations, as well as the legal authority of the region, rights and regulations in regional state administrations of Ukraine (2020). No. 1321. Retrieved from www.kmu.gov.ua/npas/pro-zatverdzhennya-poryadku-zdijsntnnya-zahodivshodo-rajonih-derzhavnih-administracij-1321-161[in Ukrainian].

About the introduction of amendments to the acts of Ukraine as well as the regulation of nutritional organization and efficiency of the organs of the muscular self-assembly and regional state administrations. (2020, November 17). No. 1009IX. Retrieved from zakon.rada.gov. ua/laws/show/1009-IX\#Text [in Ukrainian].

"Decentralization cannot be reversed or stopped" - V'yascheslav Negoda. (2020, March 17). Mirror of the week. Retrieved from zn.ua/UKRAINE/my-esche-ne-pereshli-ekvator-ekspert-o-prodvizhenii-reformy-decentralizacii-348226_. html [in Ukrainian].

Decentralization reform. (2020). Uryadovy portal. Retrieved from www.knu.gov.ua/ diyalnist / reformi / efectivne(2020) vryaduvannya / reforma-dectntralizaciyi. [in Ukrainian].

Decentralization. Uryadovy portal (2020). Retrieved from decentralization.gov.ua/news/11909.

Drannik A. Hello, quarantine! (2020, December 15). Events of the week [in Russian].

Fesenko, V. (2020). What is considered Zelenskiy's invention worked under both Kuchma and Yanukovych. Retrieved from strana.ua/opinions/305503-to-chto-schtajut-izobreteniem-zelenskogo-rabotalo-i-prikuchme-i-pri-janukoviche.htul [in Russian].

Filonov, M. (2019). Parties of Regions. Ukrainian Truth. Retrieved from pravda.com.ua/columns/2019/12/18/ [in Ukrainian].

Filonov, M. (2019). Political jackpot "43 million". What is the share of the check for the opportunity and the land? Ukrainian truth. Retrieved from pravda.com.ua/columns/2019/07/11 [in Ukrainian].

Filonov, M. (2019). The zupinka-mice vibori is coming. Ukrainian Pravda. Retrieved from pravda.com.ua/ columns/2019/08/1/7222512/ [in Ukrainian].

Filonov, M., (2020). "Servant to the people" and reform. Vibori programmed, decentralization zupinili. Ukrainska Pravda. Retrieved from pravda.com.ua/columns/2020/11/27/ [in Ukrainian].

Igor Polykhaev: Decentralization is the only right opportunity for Ukraine's development. (2020). Retrieved from 112.ua/politika/igor-kolyhaev-decentralizaciya--edinstvenno-pravilnaya-vozmozhnost-razvitiya-ukrainy-537 // $2 . \mathrm{html}$ [in Russian].

In terms of the spread of covid-19, Ukraine is second only to four European countries. (2020). Ukrainska Pravda. Retrieved from Pravda.com.ua/rus/news/2020/12/197277511/ [in Russian].

Ishchenko, F., \& Timofeev, I. (2020, May 26). Country in quarantine: how many Ukrainians were on the brink of survival. Today [in Russian].

Kostin, I. (2020, November 20-26). Kovid weekend. 2000 (weekly), 40. Retrieved from 2000.ua/v-nomere/forum/plus/ kovid-vyhodnogo-dna.htmt [in Russian].

Krivchik, H. H. (2019). Decentralization of the Ukrainian government: concept, implementation, results of the first stage (2014-2018 pp.). Universum Historiae et Archeologiae, 2 (2), 95-106. Dnipro [in Ukrainian].

Krivchik, H. H. (2019). Provisions and results of the first stage of decentralization of the Ukrainian government (2014 - 2018). Legal aspects of public administration: theory and practice: materials of the XI sciences and practical conferences. (pp. 18-21). Dnipro: DRI [in Ukrainian].

Machiavelli, N. (2019). Sovereign. On the art of war. Moskva: Publishing house AST [in Russian].

Manchuk, A. (2020). Kryvyi Rih: how Zelensky lost at home. Retrieved from ukraina.ru/opinion/20201208/1029887567. html [in Russian].

Mistsevi vybory v Ukraini [Local elections in Ukraine.]. (2020). Retrieved from uk.wikepedia.org/wiki/ Mistsevi vybory_v_Ukraini. 2020 (in Ukrainian).

More than 13 thousand private entrepreneurs closed in April. (2020, May 18). Mirror of the week. Retrieved from zn.ua/ ECONOMICS/v-aprele-zakrylis-bolee-13-tysyach-flp354614_html (in Ukrainian).

Negoda, V. (2020). Decentralization is not possible to skasuvati abo zupiniti. Retrieved from zn.ua/UKRAINE/muesche-ne-perechli-ekvator-ekspert-o-prodvzhenii-reformy-decentralizacii-348226_htm [in Ukrainian]. 
Orwell, J. (2009). Cattle yard. Chapter X. Moskva: AST [in Russian].

Popova, O. (2020). Administrative afterburner. Chim will block the accelerated reform of self-discipline. Retrieved from zn.ua/economics_of_regions/administrativnyy_forsazh-chem-ugrozhaet-uskorenie-adminreformy-345529_html [in Russian].

Prokopchuk F., (2019). Decentralization in finance: how to complete the reform in 9 months? Retrieved from hromadske. ua/posts/decentralizaciya-na-finishi-chi-zavershat-reformu-za-9-misyaciv [in Ukrainian].

Rada reduced the number of regions in Ukraine: 136 instead of 490. (2020). Ukrainian truth. Retrieved from pravda. com.ua/rus/news/2020/07/07/7259715/ [in Russian].

Saint-Exupery, A. de. (2020). Citadel. Moskva: AST KEEPER [in Russian].

Simonenko, V. (2020, October 20). Dead end of the fateful reform. Evening Odessa [in Russian].

Studennikova, G. (2020) To fire state employees, cause chaos before the elections. Why the Rada has four times reduced the number of districts. Retrieved from strana.ua/news/279322-novaja-karta-rajonov-ukrainy-zachem-ukrupnili-rajthentry. html [in Russian].

The discussion on decentralization in the regions will continue for two weeks. (2020, February 29). Interfax Ukraine. Retrieved from interfax.com.ua/news/political/644060.html [in Ukrainian].

The mayor of Cherkassy has apologized to Zelenskiy, whom he had previously sued. Retrieved from news.liga.net/ politics/news/mer-cherkass-publichnol-izvinilsya-pered-zelenskim-video [in Ukrainian].

The number of Ukrainians who have become infected with COVID has exceeded 1 million (2020). Retrieved from pravda.com.ua/news/2020/12/24/727804 [in Ukrainian].

Tomenko, M. (2021) Decentralization according to the schemes of Kaganovich's great-grandchildren. Retrieved from obozrevatel.com/person/nikolaj-tomenko.htm [in Russian].

Vedernikova, I. (2020). Without a fulcrum. Ale in one chapel. Retrieved from zn.ua/internal/bez-tochki-opori-ale-vodnomu-chovni-34353 .html [in Russian].

Evseeva, G. P., \& Krivchik, H. H. (2019). Formation of the system of miscellaneous management in Ukraine. State management and miscellaneous self-regulation, 1 (40), 13-20. Dnipro: DRIDU NADU [in Ukrainian].

Kryvchyk Hennadiy

Dr.Sc., Full. Prof., https://orcid.org/0000-0001-7504-4575, gennadijkrivcik2@gmail.com

Стаття надійшла / Article arrived: 04.01.2021

Схвалено до друку / Accepted: 20.01.2021 